\title{
Agronomic characteristics and radicular diagnosis of tropical poaceae cultivars by image processing
}

\author{
Anderson Samuel Silva ${ }^{1}$, João Paulo de Farias Ramos ${ }^{1}$, Edson Mauro Santos ${ }^{1}$, Rubens Fernandes Costa ${ }^{2}$, \\ Valdemir Ribeiro Cavalcante ${ }^{2}$, Kilmer Oliveira Soares ${ }^{1}$, Raniere de Sá Paulino ${ }^{1}$, Ana Cecilia Muniz ${ }^{1}$ \\ ${ }^{1}$ Universidade Federal da Paraíba - UFPB, Centro de Ciências Agrárias, Departamento de Zootecnia. ${ }^{2}$ Empresa de \\ Pesquisa Paraibana, Extensão Rural e Regulação Fundiária - EMPAER. E-mail: andersontacaratu@ hotmail.com
}

\begin{abstract}
This study aimed to analyze and compare the agronomic characteristics and development of the root system through digital image processing of different cultivars of tropical grasses of Brachiaria and Panicum genera. The experiment was carried out at an experimental station of the Research, Rural extension and land regularization company of Paraiba - EMPAER in Alagoinha - PB, in a rainfed agriculture system. Through June 2019 to 45 days after sowing, the grasses were cut for aerial part evaluation (biomass composition, forage yield, root system (volume and surface area) of the cultivars Mombaça, Tamani, Zuri, Massai, Piatã and Ipyporã. Occurred difference between cultivars for all variables analyzed, except for the leaf-stem ratio. The cv. Mombaça presented the best agronomic and root results, being the one that best adapted the edaphoclimatic conditions of the region. On the other hand, Ipyporã was the least expressive for forage yield and water efficiency. Through root image processing, a diagnosis is possible that reflects the forage yield of the genera Brachiaria sp. and Panicum sp.
\end{abstract}

Keywords: adaptation; forage yield; SAFIRA.

\section{Características agronômicas e diagnóstico radicular de cultivares tropicais de poaceae por processamento de imagem}

\section{Resumo}

Este estudo teve como objetivo analisar e comparar as características agronômicas e o desenvolvimento do sistema radicular através do processamento digital de imagens de diferentes cultivares de gramíneas tropicais dos gêneros Brachiaria e Panicum. $O$ experimento foi realizado em uma estação experimental da empresa de Pesquisa, Extensão Rural e Regularização Fundiária da Paraíba - EMPAER em Alagoinha - PB, em um sistema de agricultura de sequeiro. Entre junho de 2019 e 45 dias após a semeadura, as Poáceaes foram cortadas para avaliação das partes aéreas (composição da biomassa, produção de forragem, sistema radicular (volume e área superficial) das cultivares Mombaça, Tamani, Zuri, Massai, Piatã e Ipyporã. Ocorreu diferença entre as cultivares para todas as variáveis analisadas, exceto para a relação folha-caule. $\mathrm{O}$ cv. Mombaça apresentou os melhores resultados agronômicos e radiculares, sendo o que melhor adaptou as condições edafoclimáticas da região. Por outro lado, Ipyporã foi o menos expressivo para rendimento de forragem e eficiência hídrica. Através do processamento de imagens radiculares, é possível um diagnóstico que reflita a produção de forragem dos gêneros Brachiaria sp. e Panicum sp.

Palavras-chave: adaptação; produção de forragem; SAFIRA.

\section{Introduction}

Brazil stands out in the beef production scenario in the world, this success is attributed to the large area of cultivated and native pastures present in the national territory. For Parente and
Ferreira (2018), this territory occupies about 160 million hectares, which represents about $45 \%$ of Brazilian agricultural areas (IBGE, 2019), of these Poaceae, most of which are of the genus Brachiaria and Panicum. 
However, information regarding the root system of these genotypes is scarce, which can compromise the producer in decision making at the time of choosing the best cultivar to be cultivated.

The structure and architecture of the root system are related to the productivity of the plant and its morphological characteristics of the aerial part, mainly due to the irregularity in the exploitation of agricultural soils, however, the study of the root system of the pastures is of paramount importance for the future success of the production (HABERMANN et al., 2019).

Thus, the diagnosis of the root system can increase the capacity to choose the ideal genotype as a function of productive data of the aerial part and its relation to the root system.

Some environmental factors influence the root growth of the plants in the pasture, such as luminosity, humidity, amount of nutrients, temperature, as well as the plant genetic factors and the adopted pasture management (BATTISTI et al., 2018).

It is known that morphological characteristics of the root system as volume and surface area serve as an important tool to determine and monitor the growth dynamics and compare which species adapted to certain management and environmental factors that they have been submitted (ANDRADE et al., 2016).

With this in mind, the Centro Nacional de Pesquisa e Desenvolvimento de Instrumentação Agropecuária - CNPDIA, of the Empresa Brasileira de Pesquisa Agropecuária (EMBRAPA), developed the public domain SAFIRA (Fiber and Root Analysis System) software, which helps analyzes through processing of images of roots washed with high precision compared to other methods, in addition, it allows to obtain measurements of surface area, diameter, volume, among others, quantifying quickly, contributing to obtain a greater number of possible repetitions (JORGE; RODRIGUES, 2008).

This context, the present study aimed to compare the agronomic characteristics and to perform the diagnosis of the root system through image processing and its relationship with the area of different cultivars of tropical Poaceae of the genera Brachiaria sp. and Panicum sp.

\section{Material and Methods}

The experiment was carried out at the experimental station of the company Research,
Rural extension and land regularization company of Paraiba - EMPAER in Alagoinha - PB, Brazil (06 o $57^{\prime} 00$ "S, 35 o 32 ' 42 " W and altitude of 317 $\mathrm{m})$. The climate of the region is As', hot and humid, with autumn-winter rains, according to the Köppen-Geiger classification. The average annual rainfall is $995 \mathrm{~mm}$, with a rainy season from March to August; The average annual temperature varies from $22 \circ \mathrm{C}$ to $26 \circ \mathrm{C}$; and the relative humidity of the air is approximately $25 \%$. The soil of the experimental area was classified as Eutrological Planosol (SANTOS et al., 2013).

Planting was carried out by haul on June 1, 2019, in July 15, 2019 to 45 days after sowing (DAS), the grasses were cut for aerial part evaluation: biomass composition, forage yield, and root system: volume and surface area ratios, of the cultivars Mombaça, Tamani, Zuri, Massai (Panicum), Piatã and Ipyporã (Brachiaria). No fertilization was carried out in the experimental period, and all cultivars underwent the same management conditions.

Each plot of grass comprised an area of $35 \mathrm{~m}^{2}$, wherein each experimental unit, three replications were performed using a square frame with dimensions of $1 \mathrm{~m}^{2}$ to determine the agronomic characteristics and productive yield. At the time of the cut, a residue height of $15 \mathrm{~cm}$ was used, where the forage was cut and placed in identified bags, taken for weighing and subsequent manual separation of the morphological components (leaf, stem and dead material) to obtaining the mass of each component by weighing them. The mass obtained was then expressed as a percentage of the total forage mass and the stratum.

The Canopy Heights $(\mathrm{CH})$ was monitored with the aid of a scale ruler in $\mathrm{cm}$, with which the measurements were made by the experimental unit, in a zigzag direction, to compose an average of the height.

To calculate the leaf area index (LAI) the calculation of the fraction of the green leaves of the six cultivars was used and verified by the formula below:

$$
\mathrm{LAI}=\frac{\mathrm{WGL}}{(\mathrm{WGL}+\mathrm{Ws}+\mathrm{WDM}) * \mathrm{WTDM} * \mathrm{SAL} / 10000}
$$

where the LAI is given in $\mathrm{m}^{2}$ of soil area by the area occupied by the plant part in $\mathrm{m}^{2}$; WGL is the weight of green leaves (g); Ws is the weight of stem (culm) (g); WDM is the weight of the dead material (g); WTDM is the weight of the total 
dead material $\left(\mathrm{kg} \mathrm{ha}^{-1}\right)$ and SAL is the specific area of the leaf $\left(\mathrm{m}^{2} \mathrm{~kg}^{-1}\right)$ according to the methodology described by Roberts et al. (1996).

The water footprint (WF) is the volume of water in $\mathrm{m}^{3}$ used for the production of green mass of the crop, measured over the experimental period. Where it was estimated based on rain occurring at 45 DAS (Figure 2). To evaluate the WF, the methodology of Hoekstra et al. (2011) was used.

The dry matter content (DM) was determined by pre-drying in an oven at $65^{\circ} \mathrm{C}$ until constant weight (dry sample), then ground in a sieve of $2 \mathrm{~mm}$ and dried in an oven at $105 . \mathrm{C}$ for 16 hours (oven-dry sample). The forage Mass (FM) was determined by multiplying the weight of green matter (WGM) by the contents of DM. After, the rain use efficiency (RUE, $\mathrm{kg}$ of $\mathrm{DM} / \mathrm{ha} / \mathrm{mm}$ ) was measured. The RUE was determined by the relationship between FM and precipitation at 45 DAS.

To determine the volumetric density (VD), the forage mass values of the upper stratum of the canopy of each cultivar were used and divided by the value of the height of its respective residue. Thus, the forage quantity was obtained in $\mathrm{kg} \mathrm{MS.cm-}{ }^{1}$. ha- ${ }^{-1}$.

To perform the root diagnosis, $40 \mathrm{~cm}^{2}$ of the root was removed at the effective depth of the seeding line, the root growth assessments followed the method of washed roots proposed by the Embrapa Agricultural Instrumentation (JORGE, 2010). After washing, the software SAFIRA 2010-System for analysis of fibers and roots-developed by the National Center for Research and Development of agricultural instrumentation-CNPDIA, of the Brazilian Agricultural research company-EMBRAPA, was used to obtain images using a digital camera with a predefined scale of $20 \mathrm{~cm} \times 20 \mathrm{~cm}$ (JORGE; RODRIGUES, 2008).

Every procedure previously takes place the editing of the real images with a predefined scale after the morphological manipulation of the images through the watershed, used to separate roots that are touching according to the methodology proposed by Jorge (2010). The entire procedure for root analysis is described in Figure 1.

Figure 1. (A) actual image used for manipulation, (B) Watershed process, provides a selection of the roots and a superposition of others such as (C) skeletonization of the root, identifying strategic external parts of the morphology, image already manipulated ready for finalize and generate the final results.

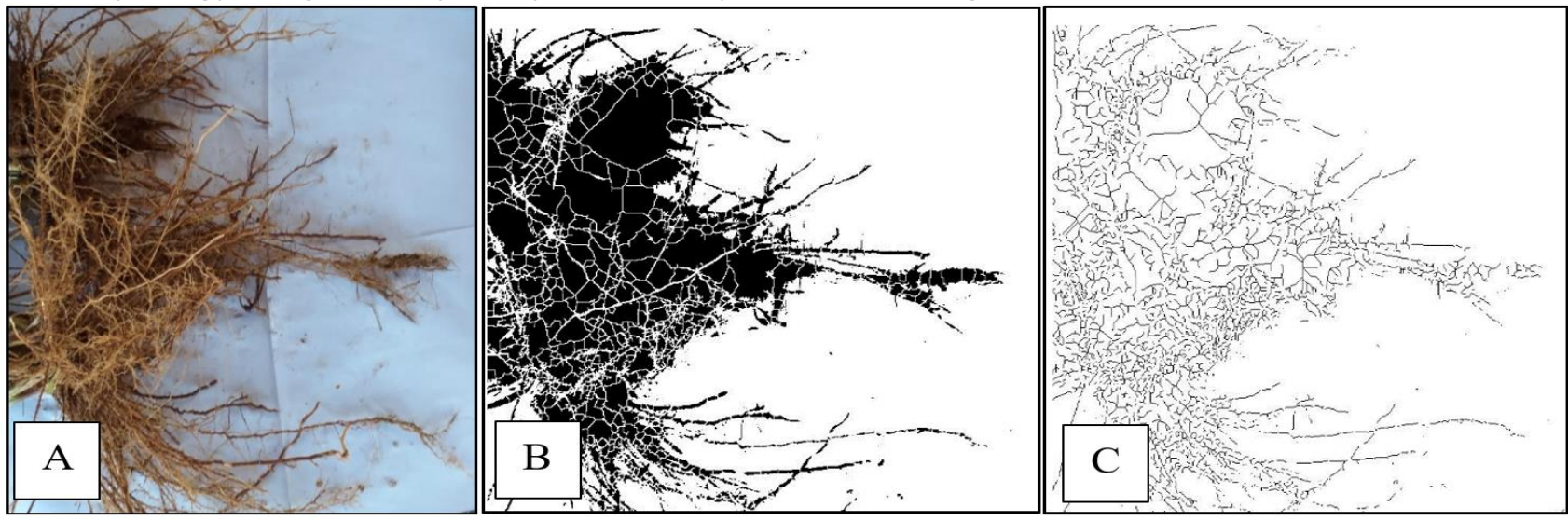

Image processing originated the data of volume $\left(\mathrm{mm}^{3}\right)$ and surface area $\left(\mathrm{mm}^{2}\right)$ of roots per sample. Due to the discrepant values obtained, data analysis of the first twenty roots were performed through the box plot (box diagram) for a better interpretation of the analyses, identifying possible outliers.
During the experimental period, the meteorological variables of rainfall $(\mathrm{mm})$ were monitored using a conventional station belonging to the EMPAER located at a few meters from the cultivation area (Figure 2). 
Figure 1. Rainfall during the experimental period in 45 days after sowing (DAS) June 1 to July 15, 2019.

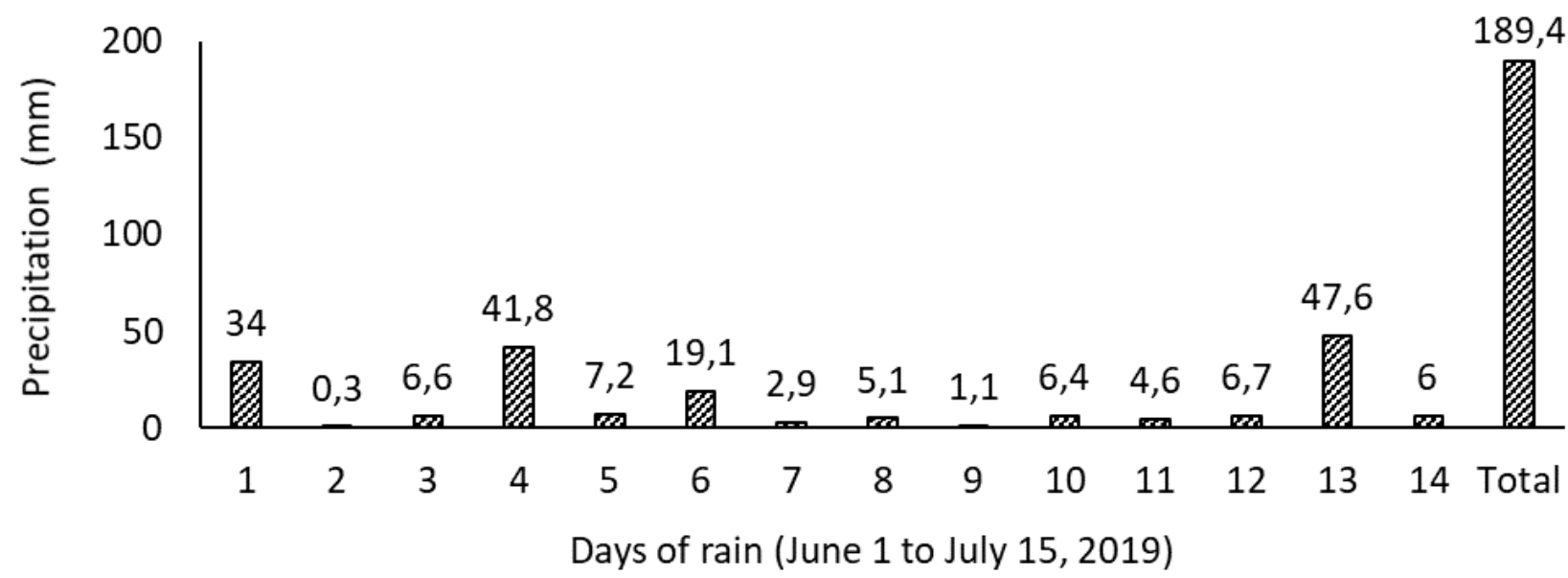

The data of the tests were subjected to analysis of variance using the software SISVAR (FERREIRA, 2011) at 5\% significance. When differences were detected, the Tukey test was compared at the same level of significance.

\section{Results and Discussion}

For all variables, there was a significant effect among the cultivars evaluated $(p<0.05)$, except for leaf: stem ratio (L/S). The water footprint (WF), forage mass (FM) and rain use efficiency (RUE) cultivars differed only concerning cv. Ipyporã, where it had a value of $1.26 \mathrm{~m}^{3}, 1.2(\mathrm{t}$ MS ha- ${ }^{1}$ ) and 0.0001 (kg MS ha- ${ }^{1} \cdot \mathrm{mm}^{-1}$ ) respectively (Table 1 ). This result is possibly justified by the lower green matter yield of this cultivar, associated with lower canopy height $(\mathrm{CH})$, what may have contributed to the results

Table 1.Productive, morphological and water efficiency characteristics of different grasses cultivars of the genus Brachiária sp. and Panicum sp.

\begin{tabular}{|c|c|c|c|c|c|c|c|c|}
\hline \multirow{2}{*}{ Variable } & \multicolumn{6}{|c|}{ Cultivar } & \multirow{2}{*}{ Valor-P } & \multirow{2}{*}{ EPM } \\
\hline & MOMBAÇA & MASSAI & ZURI & TAMANI & IPYPORÃ & PIATÃ & & \\
\hline$W F\left(m^{3}\right)$ & $0,45 a$ & $0,52 \mathrm{a}$ & $0,62 \mathrm{a}$ & $0,62 \mathrm{a}$ & $1,26 \mathrm{~b}$ & $0,76 \mathrm{a}$ & $\begin{array}{l}< \\
0,0001\end{array}$ & 9,06 \\
\hline FM (t MS ha- ${ }^{-1}$ ) & $4,90 \mathrm{a}$ & $3,80 \mathrm{a}$ & $3,26 a$ & $3,53 \mathrm{a}$ & $1,2 \mathrm{~b}$ & $2,66 \mathrm{a}$ & 0,0011 & 0,51 \\
\hline RUE (kg MS ha- ${ }^{-1} \mathrm{~mm}^{-1}$ ) & $0,002 \mathrm{a}$ & 0,002 a & $\begin{array}{l}0,001 \\
a b\end{array}$ & $0,002 \mathrm{a}$ & $0,0001 \mathrm{~b}$ & $\begin{array}{l}0,001 \\
a b\end{array}$ & 0,0074 & 0,0003 \\
\hline$B / S$ & 2,03 & 0,69 & 1,93 & 1,89 & 1,87 & 1,54 & 0,2403 & 0,39 \\
\hline WGM (t MV ha- ${ }^{-1}$ ) & 29,84 a & $\begin{array}{l}17,76 \\
a b\end{array}$ & $15,05 \mathrm{~b}$ & $19,76 \mathrm{ab}$ & $7,10 \mathrm{c}$ & $\begin{array}{l}12,70 \\
\mathrm{cb}\end{array}$ & $\begin{array}{l}< \\
0,0001\end{array}$ & 2,98 \\
\hline $\mathrm{CH}(\mathrm{cm})$ & 90,66 a & $\begin{array}{l}76,49 \\
a b\end{array}$ & $\begin{array}{l}80,93 \\
a b\end{array}$ & $81,63 a b$ & $62,20 \mathrm{~b}$ & $92,86 \mathrm{a}$ & 0,0055 & 4,26 \\
\hline $\operatorname{IAF}\left(m^{2} m-{ }^{2}\right)$ & $1,88 \mathrm{e}$ & $6,80 \mathrm{a}$ & $3,14 \mathrm{c}$ & $4,23 \mathrm{~b}$ & $3,66 \mathrm{~cd}$ & $2,52 \mathrm{~d}$ & $\begin{array}{l}< \\
0,0001\end{array}$ & 0,88 \\
\hline VD (kg MS.cm-1 ${ }^{-1}$ ha- $\left.{ }^{-1}\right)$ & $51,80 \mathrm{a}$ & 49,68 a & $39,49 \mathrm{~b}$ & $42,79 a b$ & $16,23 \mathrm{c}$ & $28,12 \mathrm{~b}$ & $\begin{array}{l}< \\
0,0001\end{array}$ & 4,63 \\
\hline
\end{tabular}

WF- Water footprint; FM- Forage mass; RUE- rain use efficiency; B\S- Blade \Stem ratio; WGM- weight of green matter; $\mathrm{CH}$ - Canopy height; LAI- leaf area index; VD- Volumetric density. Means followed by different letters in the line differ from each other by the Tukey test $(\mathrm{P}<0.05)$. GM-green matter; DM- dry matter

Elevated WF values for cv. Ipyporã indicates that it requires higher water availability to produce biomass. Unlike the other cultivars that varied values of higher and lower value from 0.76 to $0.45 \mathrm{~m}^{3}$ of water respectively.

This variable is important, especially for regions with scarcity and irregularity of rainfall, as 
the semiarid, being an indicator to evaluate the water resource available for the implantation of species with forage potential in the climate conditions of the region. In addition, it can bring relevant information for decision making when choosing the species to be cultivated.

Mekonnen and Hoekstra (2010), highlighted that the estimation of the water footprint for agriculture contributes to the knowledge about the need to use the water, as well as to promote the management and conservation of this resource increasingly scarce.

For the rain use efficiency (RUE), there was effect between cultivars $(p<0.05)$, where the grasses of the genus Panicum sp. (Mombaça, Massai and Zuri) presented the highest values with $0.002 \mathrm{~kg}$ DM $\mathrm{kg} \mathrm{MS}$.ha- ${ }^{1} . \mathrm{mm}^{-1}$, the low values of the RUE are associated with the shortest interval of time for cutting ( 45 days) and lower rainfall volume $(189.4 \mathrm{~mm})$, with only 14 days of occurrence (Figure 2 ).

Thus, in the Semiarid region, the water balance is most often negative and can reach from six to eight months of drought (SOUZA, 2013), compromising the production of forage biomass in a rainfed system. However, the cultivars of the Panicum genus present the production of more dry matter from the brachiaria, due to the greater amount of fibrous and stalk material, particular characteristics of the genus.

In the semiarid, the study of the RUE is important, which can indicate the tolerance of the grasses to conditions of low precipitation, water irregularity and unevenness distribution of rainfall, which could be verified in this study. Thus, the RUE is directly related to decisionmaking at the time of the choice of grass species to be cultivated in the rainfed system.

For the WGM there was a significant effect $(p<0.05)$, among the cultivars. The cv. Mombaça presented a higher value with 29.84 and significantly equal to Massai and Tamani both of the genus Panicum, with 17.76 and 19.76 tons of green matter per hectare respectively.

The cv. Piatã presented the highest canopy height, but a low WGM, this is justified by the IAF of this cultivar that relatively low, providing a lower accumulation of green biomass in the plant.

For $\mathrm{CH}$, there was a difference between the species $(p<0.05)$, occurring a variation of 92.86 to $60.20 \mathrm{~cm}$ from the highest to the lowest height respectively.
Hodgson (1990), affirms that $\mathrm{CH}$ is a morphological characteristic with great importance concerning the mass of the bit, being the main determinant of food intake by the animals, and may limit or not the quantity available for an animal grazing. Thus, in addition to being an important indicator in the production system, it is also a decisive transformation in the entry and exit of animals in the pasture.

The LAI also presented different values among cultivars $(p<0.05)$, and $c v$. Massai with a higher value among cultivars $\left(6.80 \mathrm{~m}^{2} \mathrm{~m}^{-2}\right)$. This is justified by the growth of cultivars that were not uniform to 45 DAS, with a variety of development, possibly due to the adaptation of different edaphoclimatic conditions between them.

Reis et al. (2013) affirm that the LAl in pastures varying from 3.0 to $5.0 \mathrm{~m}^{2} \mathrm{~m}^{-2}$, being situated in the critical value of the grasses, is when the luminous interception reaches approximately $95 \%$ of all incident light leftover leaves. Values above these can compromise the production of green biomass of leaves and increase the proportion of dead material, being increasingly the occurrence of senescence and lower growth with lower accumulation and quality of forage. Corroborating the results of this study, with an LAl above the critical as a result, the productivity of green and dry matter did not increase in the same proportion of this variable.

Concerning volumetric density (VD), the cultivars differed from each other $(p<0.05)$, presenting better results for Mombaça, Massai and Tamini, with 51.80, 49.68 and $42.79 \mathrm{~kg}$ MS.cm- ${ }^{-1}$. Ha- ${ }^{1}$ respectively. This result is justified by the values of green mass and residual height of fodder, where they are used for the determination of VD.

The VD results of the cultivars observed in this study corroborate the results established by Valle et al. (2017) which for tropical grasses

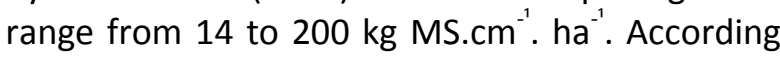
to the same author, VD is the main parameter to determine the rate of consumption by animals, thus having a positive correlation between leaf density and its relation with the stem in tropical pastures, it is also an indication of a higher nutritional value of forage.

Regarding the composition of the upper stratum of the aerial part of the forage mass of the cultivars, there was a difference between the cultivars $(p<0.05)$ for leaf blade and stem percentage (Figure 3 ). 
Figure 2. Morphological composition of the upper stratum of aerial part of Poaceae (Brachiaria sp. and Panicum sp) of different cultivars. Averages followed by different letters in the line differ from each other $(P<0.05)$ by the Tukey test.

$\square$ Leaf blade $\quad \square$ Stem $\quad \square$ Dead material

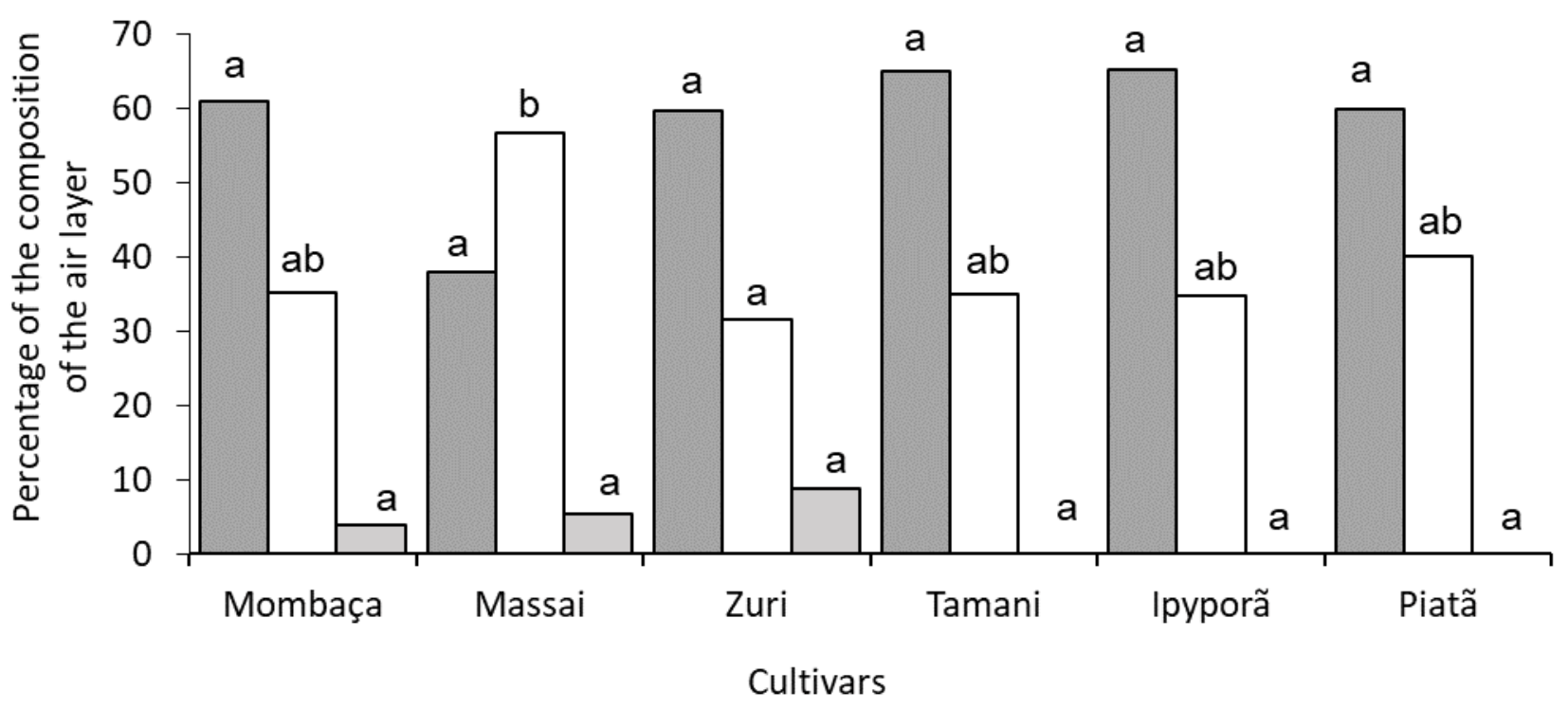

The cv. Massai for the leaf blade presented the lowest value and higher for the stem. However, the smallest proportion of stem was obtained in the cultivar Zuri, with a reduction of $44.35 \%$ compared to Massai.

The largest proportion of stem found in cv. Massai was probably associated with the high value of IAF $\left(6.80 \mathrm{~m}^{2} \cdot \mathrm{m}^{-2}\right)$, providing stretching of stems and may compromise the emergence of leaves.

Possibly these results are attributed to the shading caused by the basic leaves, or which also contributes to leaf senescence, stalk proportion and dead material. for Valle et al. (2017) the leaf area index is the main indicator of the upper forage stratum, corroborating with the present study.

For the root diagnosis through the processing of images in the box plot, it is observed that in all cultivars, both volume and root surface area, outlier values occur through the asterisk above the box, presenting discrepant values in the database and is observed by the difference in the size of the inferior stem compared with the upper stem of the data of the first twenty roots except for the volume of the cv. Mombaça (Figure 4). 
Figura 3. Box-Plot of Volume data $\left(\mathrm{mm}^{3}\right)$ and Surface area of roots $\left(\mathrm{mm}^{2}\right)$ for the identification of outliers and discrepant values of different grasses. A-Mombaça; B-Massai; C-Zuri; D-Tamani; E-Ipyporã; F-Piatã.
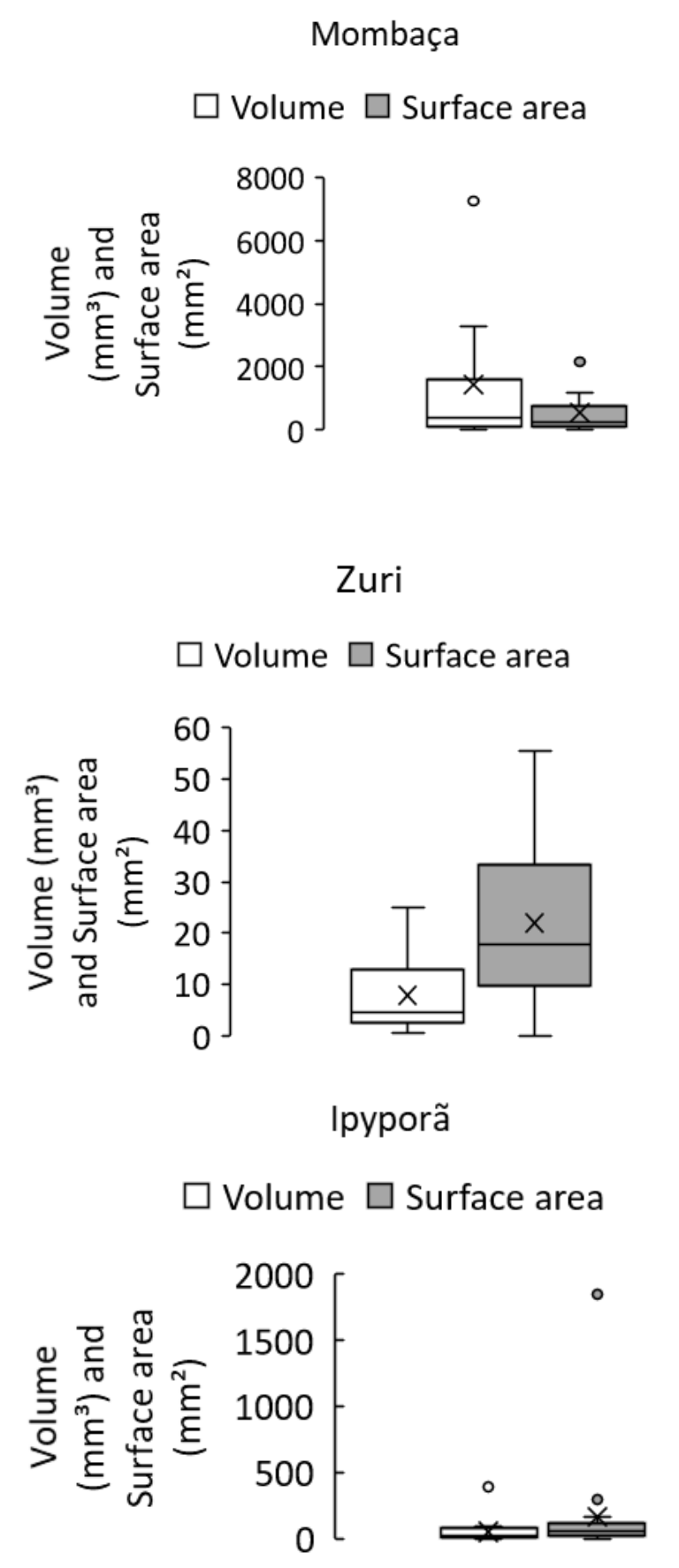

Through the box plot, we can perceive that all volumes and superficial areas of the roots have distinct values. The box of cv. Mombaça is less flattened, which indicates a low variability and standard deviation for the observed variables, and presenting mean value and median value higher than the other cultivars of grasses. On the other hand, the box plot of the cultivar Ipyporã, showed higher variability with lower median value with the narrower box compared to the other cultivars evaluated.
Massai

$\square$ Volume $\square$ Surface area

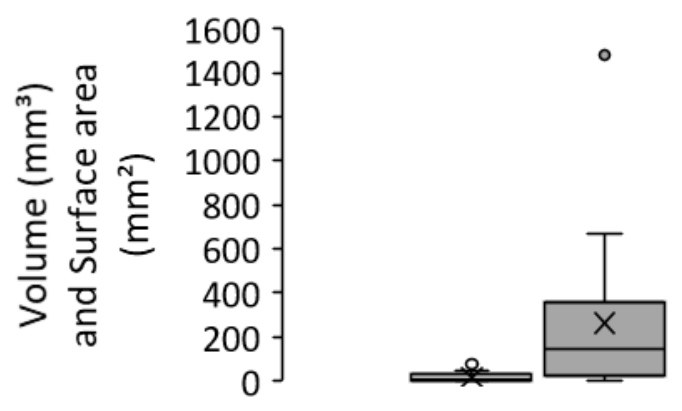

Tamani

Volume $\square$ Surface area

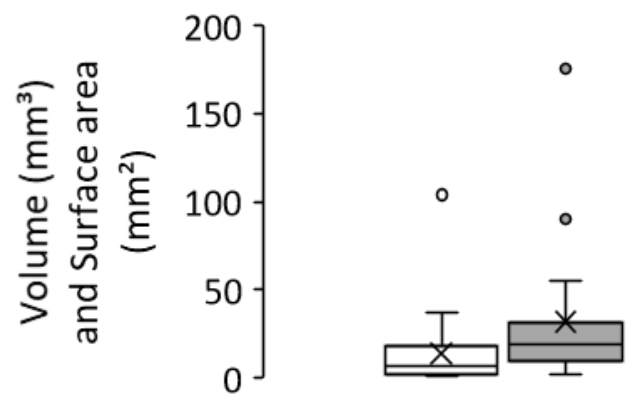

Piatã

$\square$ Volume $\square$ Surface area

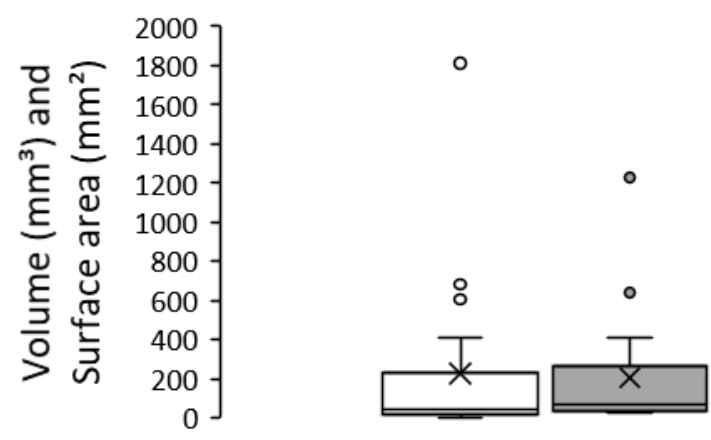

For cv. Mombaça the volume and surface area presented high values when compared to the other cultivars, this aspect is very important for the development of the plant because the root system can explore a greater volume of soil, contributing for better water and nutrient absorption.

According to Cantão (2007), the morphological characteristics of the plant root system are very important to identify the best cultivar to be cultivated, that is, the most 
adapted to the conditions that the soil is thus contributing to the growth, development and productivity of the forage plant part area. However, with the higher surface area of the roots, it means that they contain thinner roots, which may compromise the longevity of the plant.

For the visual analysis of the box plot diagram, it is observed that neither one of the cultivars nor one of the variables presented a uniform and symmetrical distribution, causing variability of the tails (lines ranging from the rectangle to the outliers) and the cultivar Mombaça presented values of the most dispersed data (larger box).

The characteristics of the roots are of fundamental importance in the choice of the best genotype, that is, the most adapted to the soil stress choices, reflecting on the greater capacity of growth, development and productivity in these conditions (PACIULLO; GOMIDE, 2016). What be observed better performance for WF, FM, WGM and VD of cv. Mombaça in relation to the other cultivars, which we can suggest that this cultivar was more adapted to the edaphoclimatic conditions at 45 days.

With the comparative box plot, we observe that the volume and surface area of the twentyfirst roots of the analysis, which only the cultivar Mombaça showed less variability of data compared to the other cultivars and without discrepant values. However, the other cultivars by the outliers found deserve a more detailed investigation and that both the volume and the superficial area of the root occur variability of the data.

\section{Conclusion}

Many factors may influence the agronomic characteristics of tropical grasses, reflecting on yield and root efficiency. However, root diagnosis by means of image processing is a very useful tool to determine the relationship between root and forage yield of the aerial part.

\section{References}

ANDRADE, AS.; SANTOS, P.M.; PEZZOPANE, J.RM.; ARAUJO, L.C.; PEDREIRA, B.C.; PEDREIRA, C.G.S.; MARIN, F.R; LARA, MAS. Simulating tropical forage growth and biomass accumulation: an overview of model development and application. Grass and Forage Science, v. 71, n.1, p. 54-65, 2016. https://doi.org/10.1111/gfs. 12177
BATTISTI, R; SENTELHAS, P.C.; PARKER, P.S.; NENDEL, C.; C'MARA, G. M. S.; FARIAS, J.RB.; BASSO, C.J. Assessment of crop-management strategies to improve soybean resilience to climate change in Southern Brazil. Crop \& Pasture Science, v. 69, p. 1-9, 2018. https://doi.org/10.1071/CP17293

CANTÃO, F. R. O. Marcadores morfológicos de raiz em genótipos de milho contrastantes para tolerância à seca em resposta a estresses de fósforo e alumínio. 2007. Dissertação (Mestre em Agronomia) - Universidade Federal de Lavras, Lavras, 2007.

FERREIRA, D. F. Sisvar: a computer statistical analysis system. Ciência e Agrotecnologia, v.35, p.1039-1042, 2011.

https://doi.org/10.1590/S1413$\underline{70542011000600001}$

HABERMANN, E.; SAN MARTIN, JAB.; CONTIN, D.R; BOSSAN, V.P.; BARBOZA, A.; BRAGA, M.R; Increasing atmospheric $\mathrm{CO} 2$ and canopy temperature induces anatomical and physiological changes in leaves of the $\mathrm{C} 4$ forage species Panicum maximum. PLoS ONE, v. 14, n. 2, e0212506.

2019.

https://doi.org/10.1371/journal.pone.0212506.

HODGSON, J. Grazing management: science into practice. New York: Wiley; Burnt Mill, Harlow, Essex: Longman Scientific and Technical, 1990.

HOEKSTRA, A. Y. How sustainable is Europe's water footprint? Water and Wastewater International, v.26, p.24-26, 2011.

IBGE. Censo Agropecuário. 2019. Disponível em: https://www.ibge.gov.br/estatisticasnovoportal/. Acesso em: 01 mar. 2019.

JORGE, L. A. C; SILVA, D. J. DA C. B. S. SAFIRA: Manual de utilização. São Carlos: Embrapa Instrumentação, 2010.

JORGE, L. A. C; RODRIGUES, A. F. O. Safira: sistema de análise de fibras e raízes. São Carlos: Embrapa, 2008. (Boletim de pesquisa e desenvolvimento- EMBRAPA)

MEKONNEN, M. M.; HOEKSTRA, A. Y. A global and high-resolution assessment of the green, blue and grey water footprint of wheat. Hydrology 
and Earth System Sciences, v.14, p.1259- 1276, 2010. https://doi.org/10.5194 / hess-14-1259$\underline{2010}$

PARENTE, L.; FERREIRA, L. Assessing the spatial and occupation dynamics of the Brazilian pasturelands based on the automated classification of MODIS Images from 2000 to 2016. Remote Sens., v. 10, 1-14. 2018. https://doi.org/10.3390/rs1004060606.

PACIULLO, D. S. C.; GOMIDE, C. A. M. As contribuições de Brachiaria e Panicum para a pecuária leiteira. In: VILELA, D.; FERREIRA, R. P.; FERNANDES, E. N.; JUNTOLLI, F. V. Pecuária de leite no Brasil: cenários e avanços tecnológicos. Brasília: Embrapa, 2016. p.167-186.

REIS, G. L.; LANA, A. M. Q.; EMERENCIANO NETO, J. V. Produção e composição bromatológica do capim-marandu, sob diferentes percentuais de sombreamento e dose de Nitrogênio. Bioscience Journal, v. 29, n. 1, p. 1606-1615, 2013.

ROBERTS, J. M.; CABRAL, O. M. R.; COSTA, J. P. DA; MCWILLIAM, A. L. C; SÁ, T.D. Na Overview of the Leaf Area Index and Physiological Measururements during ABRACOS, In: J.H.C. Gash, C.A. Nobre, J.M. Roberts and R.L. Victoria (Eds). Amazonian Deforestation and Climate, J. Wiley and Sons, New York p. 287-305, 1996.

SANTOS, H. G. Sistema Brasileiro de Classificação de Solos. 3. ed. Brasília: Embrapa, 2013.

SOUZA, C.; ANDRADE, A. P.; LIMA, J. R. S.; ANTONINO, A. C. D.; SOUZA, E. S.; SILVA, I. F. Balanço hídrico da cultura da mamona sob condições de sequeiro. Revista Brasileira de Engenharia Agrícola e Ambiental, v.17, p.3-10, $2013 . \quad$ http://dx.doi.org/10.1590/S1415$\underline{4662013000100001}$

VALLE, C.B.; EUCLIDES, V.B.P.; MONTAGNER, D.B. BRS Ipyporã ("belo começo" em guarani): híbrido de Brachiaria da Embrapa. Campo Grande: Embrapa, 2017. (Comunicado Técnico; 137) 